DOI:http://dx.doi.org/10.24093/awejtls/vol1no2.9

\title{
Co-habitality in Translation: The Comparative Case of Collocations
}

\author{
Mohammad Bin Naser \\ Department of English Language and Literature, \\ College of Arts, Kuwait University, Kuwait
}

\begin{abstract}
The Present paper examines the nature of collocations in Arabic and English as a frequent multiword item in both languages. The aim of this research is to illustrate the semantic and syntactic nature of collocations and these linguistic features' effect on translation in both Arabic and English. The supportive examples showcase the problems that might arise in the translation process and their reflection on the quality of translation and level of competence of Arab translators. The findings have shown that collocations are not open to any word, as they co-habit with a limited range of words, which is the real translation crisis for the translator. These findings were supported by a proposed lexicographical model for collocation translation, which could improve the way Arab translators transfer English and Arabic collocations when encountered during the translation process.
\end{abstract}

Keywords: Collocations, dictionary, multi-word items, restriction, translation

Cite as:Bin Naser, M. (2017). Co-habitality in Translation: The Comparative Case of Collocations. Arab World English Journal for Translation \& Literary Studies, 1(2).

DOI:http://dx.doi.org/10.24093/awejtls/vol1no2.9 